\title{
ECOLOGIZATION OF WOODWORKING INDUSTRY AS A FACTOR OF FOREST BIODIVERSITY
}

\author{
Deyneko Lyudmyla*, Kyshnirenko Oksana
}

Institute for Economics and Forecasting National Academy of Sciences of Ukraine, Kyiv, Ukraine

\section{ЕКОЛОГІЗАЦІЯ ДЕРЕВООБРОБНОЇ ГАЛУЗІ ЯК ЧИННИК ЗБЕРЕЖЕННЯ БІОРІЗНОМАНІТТЯ ЛІСІВ}

\section{Дейнеко Людмила, Кушніренко Оксана}

Received 11. 5. 2017

Revised 22. 5. 2017

Published 27. 11. 2017

\begin{abstract}
Ways to maintain the forest biodiversity in the context of woodworking industry development are explored in this paper. The purpose of this paper is to substantiate perspective ways of ecologization in woodworking industry, including conservation of resources, implementation of certification and ecological management systems that will not only facilitate economic effects, but will also constitute a precondition for saving the biodiversity of Ukrainian forests. An analysis of logging volumes during the latter years is made. Negative ecological externalities of logging increase are grounded, a loss of biodiversity - in particular. The authors consider as such externalities the following: loss of biodiversity during logging; replacement of primary forests by secondary ones that are not as productive; loss of raw wood during logging and woodworking; emission of harmful substances into the atmosphere through stationary pollution sources; creation of toxic waste; huge volumes of water consumption during production. The authors established that the main factor of woodworking enterprises' influence over the environment is the loss of biodiversity. It leads to a shift in energetic and mass exchange in the biosphere that leads to a deterioration of ecological infrastructure of human living. In addition, it weakens resistance to negative climate change. Modernization of woodworking industry by resource-conserving and waste-free technologies of wood and biomass deep processing, as well as of recycling of products from wood and paper, will decrease the ecological pressure on forest resources and facilitate maintenance of the forest biodiversity. Perspective ways of ecologization in woodworking industry are proposed, based on the best practices of European countries. This will allow for the needs of woodworking industry to be balanced with the ecological capacities of Ukraine.
\end{abstract}

Keywords: forest biodiversity; woodworking industry; ecologization; conservation of resources; in-depth woodworking maintenance

\section{Вступ}

Конвенція «Про біологічне різноманіття» відмічає, що ліси відіграють важливу економічну, соціальну й культурну роль в житті багатьох людей. Вони забезпечують не лише господарську діяльність деревиною, але й забезпечують рекреаційні можливості та сприяють покращанню здоров'я та добробуту населення, захищають джерела питної води та пом'якшують наслідки зміни клімату. Разом з цим біологічне різноманіття лісів дозволяє їм еволюціонувати, краще

\footnotetext{
*Corresponding author: Lyudmyla Deyneko, Institute for Economics and Forecasting National Academy
} of Sciences of Ukraine, Kyiv, Ukraine, $₫$ deinekolv@gmail.com 
пристосовуватись до зміни умов (як кліматичних, так і наслідків господарської діяльності) підтримувати свої функції в екосистемі та зберігати здатність до покращання якості пород деревини (Convention, 2010).

Актуальність проблеми збереження біорізноманіття лісів полягає в тому, що використання лісів в господарській діяльності призводить до його швидкої руйнації, а та практика, за якої виробництву деревини в управлінні лісами надавалось пріоритетне значення, вимагає заміни на більш збалансовану, де управління лісами тісно пов'язане з охороною біологічного різноманіття, як це передбачено Стратегічним планом у сфері збереження та сталого використання біорізноманіття на 2011 - 2020 роки (Стратегічний план..., 2010).

У статті розглядається актуальне питання: як досягти збереження різноманіття лісів в умовах зростаючого розвитку деревообробної промисловості, для якої вирубка лісів й лісозаготівля $\epsilon$ першочерговими умовами забезпечення господарської діяльності.

Наше дослідження поєднує в собі три елементи: огляд відповідної наукової літератури, аналіз стану та ступеня використання лісових ресурсів в Україні, виявлення перспективних можливостей для збереження біорізноманіття.

У аспекті питань збереження біорізноманіття, зокрема в лісовому секторі, важливим є вивчення праць зарубіжних дослідників, які присвятили свої роботи дослідженню цього питання. Так, B. Скотт Швенк, Тереза М. Донован, Вільям С. Кетон, Джаред С. Нунір (Schwenk et al., 2012) виявили, що збереження біорізноманіття лісів $\epsilon$ найбільш важливим аспектом, підкреслюючи необхідність управління ландшафтними масштабами для забезпечення повного спектру товарів та послуг екосистем. Такі вчені як Ян Д. Томпсон, Кіміко Окабе, Джейсон М. Тіліанакіс, Пушпам Кумар Эккехард, Дж. Брокерхоф Ненсі, А. Шелхорн Джон, А. Параротта, Р. Насі (Thompson et al., 2011) довели, що зростання біорізноманіття може призвести до збільшення частотності запилення, збільшення темпів боротьби зі шкідниками та зменшення популяції шкідливих організмів, підвищення продуктивності та більшої стійкості в екосистемах лісів та обґрунтували ефективні політики щодо управління збереженням біорізноманіття. Серед сучасних дослідників варто виділити праці А.Чаудхарі, С. Бурієвалов, Лян Пін Коха та С. Хелвег (Chaudhary, 2016), які обгрунтували вплив лісового господарства на багатство видів шляхом здійснення мета-аналізу найпоширеніших систем виробництва деревини по всьому світу з точки зору їх впливу на багатство місцевих видів та виявили економічні ефекти від проведення різних заходів з відновлення екосистем і лісу, відбору та утримання, зниження врожайності, звичайні вибіркові лісозаготівлі, зрошування, агролісомеліорація, лісопромислові плантації. Серед вітчизняних науковців доцільно назвати праці Ю. Туниці (Туниця, 2011), Н. Попадинського (Попадинець, 2014), які дослідили роль і місце лісової галузі у структурі промисловості України, обґрунтували стратегії підвищення конкурентоспроможності цієї сфери та, зокрема, запропонували авторське бачення екологізації соціуму.

Отже, підводячи підсумок досліджень багатьох експертів, відзначаємо, що екозбалансований розвиток лісопромислового комплексу $\epsilon$ стратегічним вирішенням низки екологічних, соціальних та економічних проблем для країн.

\section{Матеріали та методи}

В основі методології дослідження $\epsilon$ системний підхід до вивчення процесу збереження біорізноманіття лісів, за допомогою якого виявлені проблеми розглядаються 3 позицій цілісності і нерозривності об'єкта та середовища його існування, цілей і методів управління, засобів та інструментів моніторингу. Для проведення науково-дослідної роботи за темою дослідження було використано такі методи:

- огляд наукової літератури:дослідження літератури, виданоїпісля 2010 рокуза допомогою комп'ютерних запитів 3 використанням набору ключових слів: біорізноманіття, деревообробна промисловість, екологізація, ресурсозбереження, екологічні інновації; 
- структурно-функціональний (для обґрунтування інституціональних імперативів розвитку інноваційних виробництв у сфері деревообробної промисловості, виявлення факторів, що впливають на збереження біорізноманіття в господарській практиці);

- статистико-економічний (для дослідження сучасного стану та тенденцій розвитку лісопромислового комплексу).

\section{Результати та їх обговорення}

Лісові масиви України за останні роки піддались хижацькому знищенню. Станом на теперішній час відбувається зростання обсягів вирубки лісів в Україні майже на 2 \% більше ніж у 2015 році та на 21 \% більше рівня 2010 року. У 2016 р. обсяги заготівлі ліквідної деревини склали 19 605,7 тис. м³ $^{3}$ включаючи 11 294,4 тис. м так званого лісу кругляка (42 \% в загальній структурі) та 8 311,6 тис. м ${ }^{3}(58 \%)$ паливної деревини. До того ж відбуваються негативні зміни в структурі ліквідної деревини: стало більше заготовлятися деревини паливної, частка якої у 2010 році становила лише 53 \%, а у 2016 вже 58 \%. Такі диспропорції негативно впливають на забезпечення українських переробників деревиною, що також завдає значних економічних збитків нашій державі. Одночасно при цьому погіршується екологічна безпека, що призводить до непередбачуваних наслідків (рис. 1).

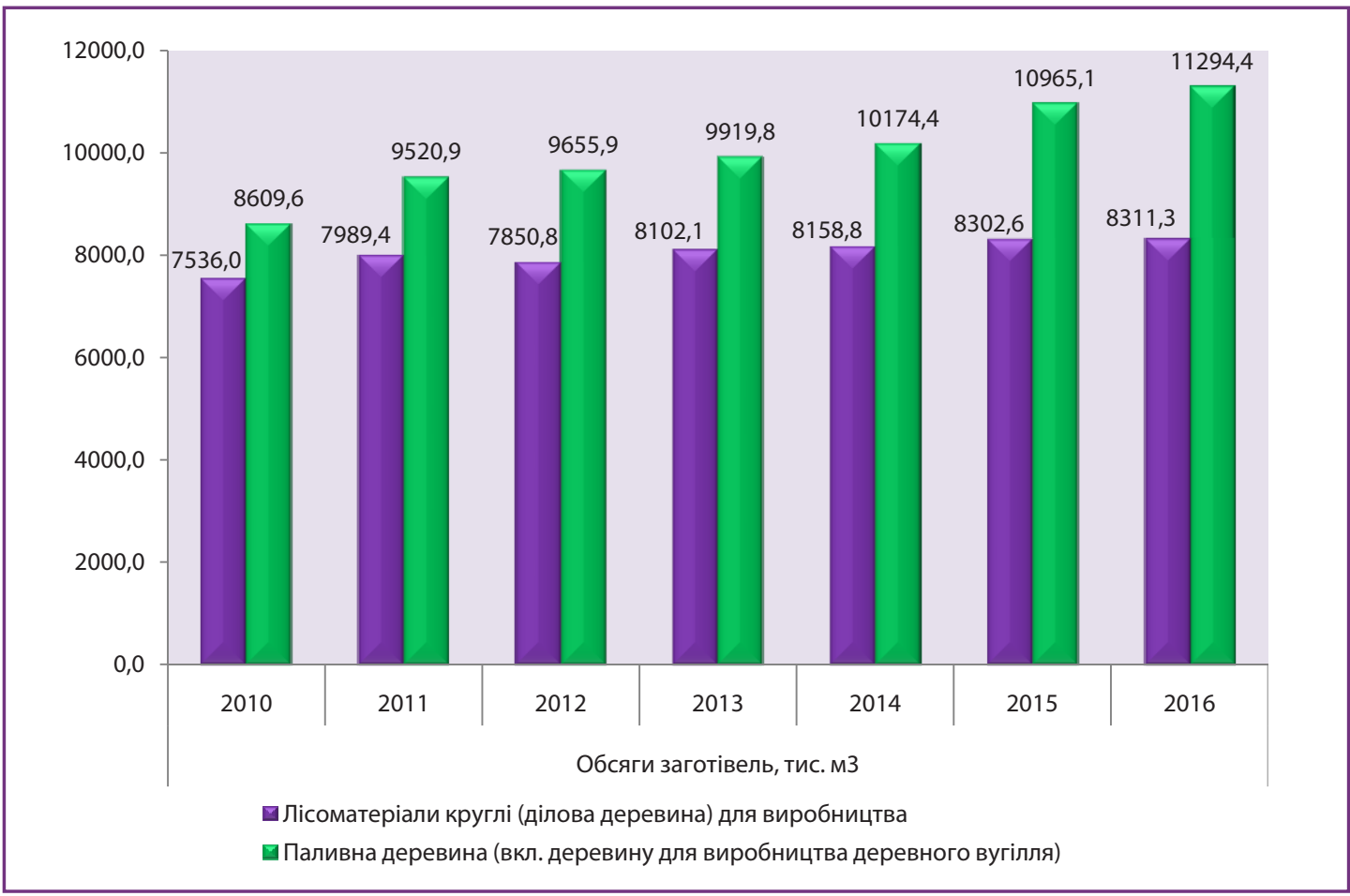

Рисунок 1 Заготівля ліквідної деревини в Україні за 2010- 2016 рр.

Figure 1 Preparation of liquid wood in Ukraine for 2010 - 2016

Для ефективного розв'язання проблеми збереження біорізноманіття важливим $\epsilon$ використання зарубіжного досвіду розвинутих країн. Європейські країни вже давно зрозуміли важливість збереження різноманіття лісів. Так, Швейцарія має цілком збережені лісові ландшафти, без облисілих ерозійних гірських схилів, що зменшило вплив природних катаклізмів. Адже Швейцарія за площею 41,3 тис. кв. км щороку заготовляє 7 млн. кубометрів 
деревини, а Українські Карпати за площею 37 тис. кв. км. заготовляють усього 1,9 млн. кубометрів. Річ у тому, що в Швейцарії рубки ведуться в межах природного приросту, тільки вибіркові або котлованні і малі за площею, із застосуванням повітряно-трелювальних установок. Деревина заготовлюється лише взимку. У лісах господарського призначення видове різноманіття захищається в законодавчому порядку.

Багато країн відмовилися від вирубки дерев на своїй території та ведуть політику заборони експорту круглого лісу та необроблених лісоматеріалів задля захисту лісів. До них належить Норвегія, Румунія й Албанія. В Албанії було введено мораторій на рубки лісу та експорт деревини з 2016 року. Заготівля можлива лише в обмежених обсягах для опалення.

Причиною такого кроку, до якого не має претензій Європа, стала катастрофічна втрата лісу, в тому числі через масові нелегальні рубки, масштабні повені та неможливість іншими способами змінити ситуацію через всепоглинаючу корупцію в цій сфері.

В Румунії діє закон, який прирівнює незаконну рубку більше як 1 гектара лісу до тероризму, тобто таким, що буде переслідуватися як посягання на національну безпеку. За останні 10 років Румунські Карпати облисіли, в країні зникало 3 гектари лісу в годину. 31 жовтня 2016 року Молдова, яка $є$ одним з ключових експортерів необробленої деревини на європейський ринок (90\% експорту - ліс-кругляк), ввела мораторій на вирубку дерев до 2020 року в державних лісах (87 \% лісів). Метою такого заходу $\epsilon$ захист від обезліснення та захист біорізноманіття лісових систем.

Успішним прикладом є досвід Фінляндії, в якій для збереження біологічного різноманіття природи створена національна програма дій, що ґрунтується на Конвенції ООН про біологічне різноманіття. Збереження біорізноманіття лісів забезпечується шляхом збільшення площ охоронюваних лісів, поліпшення їх якості внаслідок відновлювальних заходів, а також подальшого розвитку раціонального і екологічного лісокористування зі збереженням природного балансу в лісах господарського призначення.

Основою екологічної політики $Є С$ в сфері збереження біорізноманяття $\epsilon$ План дій $\in С$ щодо захисту прав лісового законодавства, управління і торгівлі (FLEGT), вагому роль в яком відіграють заходи щодо боротьби з незаконними рубками лісу і торгівлею.

Длязбереження біорізноманіття лісів України сьогодні першочерговим завданнямєекологізація деревообробної промисловості та впровадження інноваційних технологій 3 поглибленої переробки деревини для виробництва у ньому сучасної продукції, яка відповідала би новітнім світовим вимогам щодо екологічності та енергоефективності.

Екологізація деревообробної промисловості сьогодні, на нашу думку, містить такі елементи: екологічний менеджмент, ресурсозбереження та сертифікація всіх господарських процесів в ланцюгу: заготівля-переробка-відновлення лісів.

Європейська сертифікація готової продукції з деревини враховує комплекс екологічних, економічних та соціальних аспектів переробки деревини й безпечного лісокористування. Домінуючими системами сертифікації в Європі $\epsilon$ PEFC (Загальноєвропейська система лісової сертифікації) та FCS Лісова опікунська рада) - міжнародні некомерційні, неурядові організації, націлені на просування сталого лісокористування шляхом незалежної сертифікації третьою стороною. Основним засобом $\epsilon$ підписання добровільних угод про партнерство та дотримання Правил заготівлі лісоматеріалів (EUTR). Регламент ЄС вимагає від операторів створення «системи належної сумлінності» (Due diligence system), яка дозволить звести до мінімуму ризик потрапляння на ринок незаконної деревини або продукції з неї. До того ж, системи сертифікації в $\in C$ (PEFC, FCS) для продукції деревообробної галузі націлені на комплекс екологічних, економічних та соціальних аспектів переробки деревини й безпечного лісокористування. 
Ресурсозбереження в деревообробній промисловості слід розглядати як раціональне використання малоцінної деревної сировини, що дозволяє отримувати будівельні матеріали та вироби з необхідними експлуатаційними властивостями та сприяє вирішенню двох взаємопов'язаних стратегічних завдань забезпечення населення доступним і комфортним житлом і розвитком виробництв з поглибленою переробкою деревини.

щоб залишитися конкурентними, компаніям необхідно впроваджувати системи екологічного менеджменту, зокрема ISO 14001 - міжнародний загальновизнаний стандарт „Системи екологічного менеджменту“, розроблений ICO (Міжнародною організацією зі стандартизації), що діє як комплексна структура для забезпечення відповідності законодавчим вимогам. Впровадження системи екологічного менеджменту $\epsilon$ надійним способом визначення і контролю впливу виробництва на навколишнє середовище, що також впливає на зниження витрат завдяки поліпшенню продуктивності і ефективності, зниження кількості відходів та підвищення енергоефективності для зниження операційних витрат.

\section{Висновки}

Підсумовуючи, можна стверджувати, що біорізноманіття $\epsilon$ невід'ємною частиною практично всіх екосистемних процесів, при цьому деякі види відграють ключову функціональну роль та необхідні для збереження цінності екосистем. Важливим чинником збереження біорізноманіття лісів в Україні при одночасному розвитку виробництва продукції з деревини 3 високою частиною доданої вартості $\epsilon$ екологізація деревообробної промисловості, ключовими заходами в якій $\epsilon$ ресурсозбереження, впровадження систем сертифікації та екологічного менеджменту.

\section{Література}

Chaudhary, A., Burivalova, Z., Koh, L.P., Hellweg, S. 2016. Impact of Forest Management on Species Richness: Global Meta-Analysis and Economic Trade-Offs. In Sci. Rep., 6. Available at: https://www.nature.com/ articles/srep23954.pdf

Convention on Biological Diversity. 2010. Available at: https://www.cbd.int/undb/media/factsheets/undbfactsheets-ru-web.pdf

FLEGT Proposal for an EU Action Plan, 21 May 2003. Communication from the Commission to the Council and the European Parliament. Available at: https://ec.europa.eu/europeaid/ eu-action-plan-forest-law-enforcement-governance-and-trade-flegt_en

Schwenk, W. S., Donovan, T.M., Keeton, W. S., Nunery J. S. 2012. Carbon storage, timber production, and biodiversity: comparing ecosystem services with multi-criteria decision analysis. In Ecological Society of America, vol. 22, no. 5, pp. 1612-1627.

Thompson, I.D., Okabe, K., Tylianakis, J.M., Kumar, P., Brockerhoff, E.G., Schellhorn, N.A., Parrotta, J.A., Nasi, R. 2011. Forest Biodiversity and the Delivery of Ecosystem Goods and Services: Translating Science into Policy. In BioScience, vol. 61, no. 12, p. 972-981.

Попадинець, Н.М. 2014. Внутрішній ринок продукції лісової промисловості України : проблеми та напрями розвитку: монографія. Львів : ІРД НАН України, 182 с.

Стратегічний план з біорізноманіття на 2011-2020 роки. 2010. Available at: http://www.menr.gov.ua/ docs/protection6/vykonannya/convencia/CBD_Strateg_plan_bioriznomanittya_2011_2020.doc

Туниця, Ю. 2011. Екологізація економіки: теоретико-методологічний аспект. Економічна теорія, вип. 2, c. 5-15. 